\title{
BEBERAPA FAKTOR YANG BERHUBUNGAN DENGAN PERILAKU PEKERJA DALAM PENERAPAN SAFE BEHAVIOR DI PT. HANIL JAYA STEEL
}

\author{
FACTORS RELATED TO WORK BEHAVIOR IN SAFE BEHAVIOR APPLICATION \\ IN PT. HANIL JAYA STEEL
}

\author{
Nindya Septiani \\ Balai Keselamatan dan Kesehatan Kerja (K3) Bandung, Jawa Barat \\ E-mail: nindcup@gmail.com
}

\begin{abstract}
Occupational Safety and Health (OSH) behavior is influenced by predisposing, enabling, and reinforcing factors. Occupational accidents caused by various factors at work can be avoided, if the worker and the company management have a good will to prevent it. OSH behavior is necessary for the prevention of occupational accidents. The purpose of this research was to describe the association between predisposing, enabling and reinforcing factors with behavior of workers (mill line rolling mill 3) on the implementation of safe behavior in PT. Hanil Jaya Steel. This was an observational descriptive study with cross sectional approach and carried out among 26 respondents. The variables studied were age, length of employment, level of knowledge, attitude, frequency of worker's OSH training, frequency of OSH training which provide by the company, availability of personal protector equipment, regulation assembly, standard operational procedures assembly, co-workers support, supervisor's support, reward, punishment and safe behavior. The strength of relationship between variables were analyzed by using Contingency Coefficient $(C)$. The results showed that there were weak association between level of knowledge, frequency of worker's OSH training and behavior $(C=0.085$ and $C=0.255$, respectively). There were moderate association between age, length of employment, co-workers support and behavior ( $C$ $=0.398, C=0.328$ and $C=0.400$, respectively). And Also there was strong association between attitude and behavior $(C=0.556)$. It is recommended that the company providing OSH training section frequently for all workers, improving the monitoring system of workers, and providing reward and punishment program, in order to improve their safe behavior in preventing occupational accident in workplace.
\end{abstract}

Keywords: predisposing, enabling, reinforcing, safe behavior

\begin{abstract}
ABSTRAK
Perilaku K3 dipengaruhi oleh faktor predisposisi, faktor pemungkin, dan faktor penguat. Kecelakaan kerja yang disebabkan oleh berbagai faktor dalam pekerjaan bisa dihindarkan, apabila pekerja dan pimpinan perusahaan ada kemauan baik untuk mencegahnya. Perilaku K3 diperlukan untuk pencegahan kecelakaan kerja. Tujuan penelitian ini adalah untuk mendeskripsikan hubungan antara faktor predisposisi, faktor pemungkin, dan faktor penguat mengenai perilaku pekerja (unit mill line rolling mill 3) terhadap penerapan perilaku aman di PT. Hanil Jaya Steel. Penelitian ini merupakan penelitian observasional deskriptif dengan pendekatan cross sectional dan dilakukan pada 26 responden. Variabel yang diteliti adalah umur, masa kerja, tingkat pengetahuan, sikap, frekuensi pelatihan K3, frekuensi penyelenggaraan pelatihan K3, ketersediaan APD, penempelan/pemasangan peraturan, penempelan/pemasangan SOP, dukungan teman kerja, dukungan pimpinan/pengawas, reward, punishment dan perilaku aman. Kuat hubungan antar variabel dianalisis dengan menggunakan uji Koefisien Kontingensi (C). Hasil penelitian menunjukkan terdapat hubungan yang lemah antara pengetahuan dan frekuensi pelatihan $\mathrm{K} 3$ dengan perilaku aman $(\mathrm{C}=0,085$ dan $\mathrm{C}=0,255$, berturut-turut). Terdapat hubungan yang sedang antara umur, masa kerja, dukungan teman kerja dengan perilaku aman $(C=0,398, C=0,328$ dan $C=0,400$, berturut-turut $)$ serta terdapat hubungan yang kuat antara sikap dengan perilaku aman $(\mathrm{C}=0,556)$. Disarankan bagi pihak perusahaan untuk mengadakan pelatihan K3 secara berkelanjutan kepada semua pekerja, meningkatkan sistem pengawasan pekerja, serta mengadakan program reward dan punishment dalam rangka meningkatkan penerapan perilaku aman pekerja dalam pencegahan kecelakaan kerja di tempat kerja.
\end{abstract}

Kata kunci: predisposisi, pemungkin, penguat, perilaku aman 


\section{PENDAHULUAN}

Industri di Indonesia sedang mengalami perkembangan yang sangat pesat seiring kemajuan ilmu teknologi. Proses industrialisasi masyarakat Indonesia semakin cepat berkembang dengan berdirinya perusahaan atau lapangan pekerjaan yang beragam. Perkembangan industri yang pesat ini diiringi pula oleh meningkatnya risiko bahaya karena penggunaan mesin dan peralatan kerja yang semakin kompleks untuk mendukung proses produksi tersebut. Hal ini dapat menimbulkan masalah kesehatan dan keselamatan kerja di tempat kerja.

Di Indonesia, ribuan kecelakaan terjadi di tempat kerja setiap tahunnya yang menimbulkan kerusakan material, gangguan proses produksi dan menimbulkan korban jiwa. Berdasarkan data Jamsostek, pada tahun 2007 tercatat 65.474 kasus kecelakaan yang terjadi di tempat kerja yang mengakibatkan 1.451 orang meninggal, 5.326 orang cacat tetap, dan 58.697 orang cidera (Ramli, 2010).

Pada awal tahun 1980-an muncul pandangan baru mengenai K3 yaitu behavioral safety. Behavioral safety lebih menekankan pada aspek perilaku manusia terhadap terjadinya kecelakaan di tempat kerja. Studi penelitian yang dilakukan oleh Heinrich pada tahun 1941 mengenai penyebabpenyebab kecelakaan, menghasilkan kesimpulan bahwa penyebab kecelakaan kerja $88 \%$ disebabkan oleh unsafe act, 10\% dikarenakan unsafe condition, dan $2 \%$ tidak diketahui penyebabnya (Suma'mur, 2009). Pekerja cenderung berperilaku tidak aman dengan mengabaikan keselamatan walaupun itu sangat penting untuk keselamatannya. Sebagai contoh, dalam melaksanakan pekerjaannya pekerja seringkali tidak mengikuti Standard Operational Procedure (SOP) dan hanya bekerja berdasarkan pengalamannya saja. Masalah lain yang ada adalah pekerja seringkali tidak menggunakan Alat Pelindung Diri (APD) yang sudah disediakan dengan berbagai alasan (Syaaf, 2008).

Geller (2001) mengemukakan pentingnya pendekatan perilaku yang didasari oleh keselamatan (behavior based safety) dalam upaya meningkatkan keselamatan kerja. Dengan meningkatnya kesehatan dan keselamatan kerja maka dapat meningkatkan produktivitas pekerja yang pada akhirnya dapat meningkatkan kemajuan dan kesejahteraan. Selain itu, manusia merupakan salah satu aset terbesar dalam mencapai keberhasilan perusahaan. Sehingga perlu adanya penelitian faktor apa saja yang berhubungan dengan terbentuknya perilaku aman tenaga kerja baik internal maupun eksternal.

PT. Hanil Jaya Steel yang berada di Waru, Sidoarjo Jawa Timur merupakan salah satu dari perusahaan yang bergerak di bidang produksi baja. Penggunaan teknologi baru serta penggunaan berbagai mesin dan peralatan berat serta alat bantu yang serba modern dan juga penggunaan berbagai bahan kimia yang menunjang proses produksi tentunya tidak dapat dihindari lagi. Dimana proses produksinya tentu mengandung berbagai potensi bahaya yang berisiko terhadap keselamatan dan kesehatan kerja dan dapat menimbulkan kecelakaan kerja.

PT. Hanil Jaya Steel banyak melibatkan pekerja pria sebagai operator karena tingkat beban pekerjaan dan risiko paparan yang berat. Di area rolling mill terdapat proses pembentukan baja yang memiliki potensi bahaya antara lain terpeleset, paparan panas, tertimpa material dan lain sebagainya. Risiko kecelakaan kerja dia area rolling mill sering sekali terjadi dibandingkan dengan area produksi lainnya. Berdasarkan data kecelakaan kerja tahun 2013 frekuensi terjadinya kecelakaan di area rolling mill sebesar 59\% dari 98 kasus kecelakaan kerja yang terjadi di tahun tersebut, dimana sebagian besar kasus kecelakaan diakibatkan oleh unsafe action. Kecelakaan kerja tersebut tentu merugikan pekerja dan perusahaan.

Dari semua potensi bahaya yang ada akan berakibat serius apabila tidak ditangani dengan serius pula. Salah satu usaha untuk mengurangi kecelakaan kerja dan meningkatkan safety performance dapat dicapai adalah dengan memfokuskan pada pengurangan unsafe act dimana penyebab kecelakaan terbesar adalah akibat unsafe act.

Berdasarkan penjelasan di atas, penulis terdorong untuk melakukan penelitian sehubungan beberapa faktor yang berhubungan dengan perilaku pekerja dalam penerapan safe behavior di PT. Hanil Jaya Steel.Tujuan penelitian ini adalah mempelajari beberapa faktor yang berhubungan dengan perilaku pekerja dalam penerapan safe behavior di PT. Hanil Jaya Steel.

\section{METODE}

Jenis penelitian ini merupakan penelitian deskriptif dengan rancangan penelitian cross sectional. Populasi penelitian adalah seluruh pekerja di bagian mill line rolling mill 3 PT. Hanil Jaya Steel sejumlah 26 orang. 
Variabel yang diteliti adalah umur, masa kerja, tingkat pengetahuan, sikap, frekuensi pelatihan K3, frekuensi penyelenggaraan pelatihan $\mathrm{K} 3$, ketersediaan APD, pemasangan peraturan, pemasangan SOP, dukungan teman kerja, dukungan pimpinan/pengawas, reward, punishment dan perilaku aman pekerja.

Data yang diperoleh akan diolah dan variabel yang akan dihubungkan, dideskripsikan menggunakan uji koefisien kontingensi sehingga peneliti akan mengetahui kuat hubungan antar variabel.

\section{HASIL}

\section{Faktor Predisposisi}

Umur

Mayoritas responden yaitu sebesar 57,7\% termasuk dalam umur $>40$ tahun.

\section{Masa Kerja}

Mayoritas responden yaitu sebesar 57,7\% memiliki masa kerja antara 13-24 tahun.

\section{Tingkat Pengetahuan}

Mayoritas responden yaitu sebesar 76,9\% memiliki tingkat pengetahuan tentang perilaku aman dalam kategori baik.

\section{Sikap}

Mayoritas responden yaitu sebesar $88,5 \%$ memiliki sikap tentang perilaku aman dalam kategori baik.

\section{Frekuensi Pelatihan K3}

Mayoritas responden yaitu sebesar 42,3\% memiliki frekuensi pelatihan K3 dalam kategori sedang.

\section{Faktor Pemungkin}

\section{Frekuensi Penyelenggaraan Pelatihan K3}

Penyelenggaraan pelatihan K3 yang diadakan oleh perusahaan termasuk dalam kategori sedang. Perusahaan mengadakan pelatihan K3 sebanyak 1 kali dalam 1 tahun, tetapi belum merata pada seluruh pekerja.

\section{Ketersediaan APD}

Ketersediaan APD terhadap jumlah pekerja di perusahaan termasuk dalam kategori baik yaitu memenuhi jumlah seluruh pekerja.

\section{Pemasangan Peraturan}

Tidak ada pemasangan peraturan terkait larangan dan kewajiban pekerja di area kerja sehingga termasuk dalam kategori kurang.

\section{Pemasangan SOP}

Tidak ada pemasangan SOP di area kerja sehingga termasuk dalam kategori kurang.

\section{Faktor Penguat}

\section{Dukungan Teman Kerja}

Mayoritas responden yaitu sebesar 50,0\% memperoleh dukungan teman kerja dalam kategori sedang.

\section{Dukungan Pimpinan/Pengawas}

Dukungan yang diberikan oleh pimpinan/ pengawas termasuk dalam kategori baik.

\section{Reward}

Tidak ada pelaksanaan pemberian reward di tempat kerja, sehingga termasuk dalam kategori kurang.

\section{Punishment}

Tidak ada pelaksanaan pemberian punishment di tempat kerja, sehingga termasuk dalam kategori kurang.

\section{Perilaku Aman}

Mayoritas responden yaitu sebesar 69,2\% termasuk dalam perilaku aman kategori sedang.

\section{Hubungan Faktor Prediposisi dengan Perilaku} Aman

\section{Hubungan antara Umur dengan Perilaku Aman Responden}

Data tabulasi silang antara umur dengan perilaku aman pekerja di bagian mill line rolling mill 3 Juni 2014 pada Tabel 1. 
Tabel 1. Hubungan antara Umur dengan Perilaku Responden

\begin{tabular}{cccccc}
\hline \multirow{2}{*}{$\begin{array}{c}\text { Umur } \\
\text { (tahun) }\end{array}$} & \multicolumn{3}{c}{ Perilaku Aman } & \multirow{2}{*}{ Total } & \\
\cline { 2 - 4 } & Kurang & Cukup & Baik & & \\
\cline { 2 - 4 } & $\mathbf{n ~ ( \% )}$ & $\mathbf{n ~ ( \% )}$ & $\mathbf{n ~ ( \% )}$ & $\mathbf{N ~ ( \% )}$ & \\
\cline { 1 - 4 } $18-29$ & 1 & 0 & 1 & 2 & $\mathrm{C}=$ \\
& 50 & 0 & 50 & 100 & 0,456 \\
$30-39$ & 1 & 8 & 0 & 9 & \\
& 11,1 & 88,9 & 0 & 100 & \\
$>40$ & 3 & 10 & 2 & 15 & \\
& 20 & 66,7 & 13,3 & 100 & \\
\hline \multirow{2}{*}{ Total } & 5 & 18 & 3 & 26 & \\
\hline & 19,2 & 69,2 & 11,5 & 100 & \\
\hline
\end{tabular}

Dari hasil uji statistik dengan menggunakan kontingensi diperoleh koefisien kontingensi sebesar 0,456 , maka kuat hubungan antara perilaku berdasarkan umur responden adalah sedang.

\section{Hubungan antara Masa Kerja dengan Perilaku Aman Responden}

Data tabulasi silang antara masa kerja dengan perilaku aman pekerja di bagian mill line rolling mill 3 Juni 2014 pada Tabel 2.

Berdasarkan uji statistik kontingensi diperoleh koefisien kontingensi 0,328 maka kuat hubungan antara masa kerja dengan perilaku aman responden adalah sedang.

\section{Hubungan antara Tingkat Pengetahuan tentang Perilaku Aman dengan Perilaku Aman Responden}

Berikut ini adalah data tabulasi silang antara tingkat pengetahuan dengan perilaku aman pekerja di bagian mill line rolling mill 3 Juni 2014 pada Tabel 3 .

Tabel 2. Hubungan antara Masa Kerja dengan Perilaku Responden

\begin{tabular}{|c|c|c|c|c|c|}
\hline \multirow{3}{*}{$\begin{array}{c}\text { Masa Kerja } \\
\text { (tahun) }\end{array}$} & \multicolumn{3}{|c|}{ Perilaku Aman } & \multirow{2}{*}{ Total } & \multirow{9}{*}{$\begin{array}{c}\mathrm{C}= \\
0,328\end{array}$} \\
\hline & Kurang & Cukup & Baik & & \\
\hline & $\begin{array}{c}n \\
(\%)\end{array}$ & $\begin{array}{c}n \\
(\%)\end{array}$ & $\begin{array}{c}n \\
(\%)\end{array}$ & $\begin{array}{c}\mathrm{N} \\
(\%)\end{array}$ & \\
\hline \multirow{2}{*}{$1-12$} & 1 & 5 & 1 & 7 & \\
\hline & 14,3 & 71,4 & 14,3 & 100 & \\
\hline \multirow{2}{*}{$13-24$} & 2 & 11 & 2 & 15 & \\
\hline & 13,3 & 73,3 & 13,3 & 100 & \\
\hline \multirow{2}{*}{$\geq 25$} & 2 & 2 & 0 & 4 & \\
\hline & 50 & 50 & 0 & 100 & \\
\hline \multirow{2}{*}{ Total } & 5 & 18 & 3 & 26 & \\
\hline & 19,2 & 69,2 & 11,5 & 100 & \\
\hline
\end{tabular}

Tabel 3. Hubungan Antara Tingkat Pengetahuan dengan Perilaku Responden

\begin{tabular}{cccccc}
\hline & \multicolumn{3}{c}{ Perilaku Aman } & Total & \\
\cline { 2 - 5 } $\begin{array}{c}\text { Tingkat } \\
\text { Pengetahuan }\end{array}$ & Kurang & Cukup & Baik & & \\
\cline { 2 - 5 } & $\mathbf{n}$ & $\mathbf{n}$ & $\mathbf{n}$ & $\mathbf{N}$ & \\
$\mathbf{( \% )}$ & $\mathbf{( \% )}$ & $\mathbf{( \% )}$ & $\mathbf{( \% )}$ & $\mathrm{C}=$ \\
\multirow{2}{*}{ Cukup } & 1 & 5 & 1 & 7 & 0,085 \\
& 14,3 & 71,4 & 14,3 & 100 & \\
Baik & 4 & 13 & 2 & 19 & \\
& 21,1 & 68,4 & 10,5 & 100 & \\
\hline \multirow{2}{*}{ Total } & 5 & 18 & 3 & 26 & \\
& 19,2 & 69,2 & 11,5 & 100 & \\
\hline
\end{tabular}

Berdasarkan uji statistik kontingensi diketahui koefisien kontingensi 0,085 sehingga kuat hubungan antara tingkat pengetahuan dengan perilaku aman responden adalah lemah.

\section{Hubungan antara Sikap Tentang Perilaku Aman dengan Perilaku Aman Responden}

Data tabulasi silang antara sikap dengan perilaku aman pekerja di bagian mill line rolling mill 3 Juni 2014 pada Tabel 4.

Hasil uji statistik menggunakan uji kontingensi menunjukkan koefisien kontingensi 0,556 maka kuat hubungan antara sikap dengan perilaku aman responden adalah kuat.

\section{Hubungan antara Frekuensi Pelatihan K3 dengan Perilaku Aman Responden}

Data tabulasi silang antara frekuensi pelatihan K3 dengan perilaku aman pekerja di bagian mill line rolling mill 3 Juni 2014 pada Tabel 5 .

Tabel 4. Hubungan antara Sikap dengan Perilaku Responden

\begin{tabular}{cccccc}
\hline & \multicolumn{3}{c}{ Perilaku Aman } & Total & \\
\cline { 2 - 5 } Sikap & Kurang & Cukup & Baik & & \\
\cline { 2 - 5 } & $\mathbf{n}$ & $\mathbf{n}$ & $\mathbf{n}$ & $\mathbf{N}$ & \\
\cline { 2 - 5 } Cukup & 1 & 0 & 2 & 3 & 0,556 \\
& 33,3 & 0 & 66,7 & 100 & \\
Baik & 4 & 18 & 1 & 23 & \\
\cline { 1 - 4 } Total & 17,4 & 78,3 & 4,3 & 100 & \\
& 5 & 18 & 3 & 26 & \\
\hline
\end{tabular}


Tabel 5. Hubungan antara Frekuensi Pelatihan K3 dengan Perilaku Responden

\begin{tabular}{cccccc}
\hline \multirow{2}{*}{$\begin{array}{c}\text { Frekuensi } \\
\text { Pelatihan } \\
\text { K3 }\end{array}$} & \multicolumn{3}{c}{ Perilaku Aman } & \multirow{2}{*}{ Total } & \\
\cline { 2 - 4 } & Kurang & Cukup & Baik & & \\
\cline { 2 - 5 } & $\mathbf{n}$ & $\mathbf{n}$ & $\mathbf{n}$ & $\mathbf{N}$ & \\
Kurang & 1 & $\mathbf{( \% )}$ & $\mathbf{( \% )}$ & $\mathbf{( \% )}$ & \\
& 16,7 & 66,7 & 16,7 & 100 & 0,255 \\
Cukup & 2 & 7 & 2 & 11 & \\
& 18,2 & 63,6 & 18,2 & 100 & \\
Baik & 2 & 7 & 0 & 9 & \\
& 22,2 & 77,8 & 0 & 100 & \\
\hline \multirow{2}{*}{ Total } & 5 & 18 & 3 & 26 & \\
\hline
\end{tabular}

Hasil uji statistik menggunakan uji kontingensi menunjukkan koefisien kontingensi 0,255 maka kuat hubungan antara frekuensi pelatihan K3 dengan perilaku aman responden adalah lemah.

\section{Hubungan Faktor Penguat dengan Perilaku Aman}

\section{Hubungan antara Dukungan Teman Kerja dengan Perilaku Aman Responden}

Berikut ini adalah data tabulasi silang antara dukungan teman kerja dengan perilaku aman pekerja di bagian mill line rolling mill 3 Juni 2014 pada Tabel 6.

Berdasarkan uji statistik menggunakan uji kontingensi diperoleh koefisien kontingensi 0,400 sehingga kuat hubungan antara dukungan teman kerja dengan perilaku aman responden adalah sedang.

Tabel 6. Hubungan antara Dukungan Teman Kerja dengan Perilaku Responden

\begin{tabular}{cccccc}
\hline \multirow{2}{*}{$\begin{array}{c}\text { Dukungan } \\
\text { Teman } \\
\text { Kerja }\end{array}$} & \multicolumn{3}{c}{ Perilaku Aman } & \multirow{2}{*}{ Total } & \\
\cline { 2 - 4 } & Kurang & Cukup & Baik & & \\
\cline { 2 - 5 } & $\mathbf{n}$ & $\mathbf{n}$ & $\mathbf{n}$ & $\mathbf{N}$ & \\
\hline Kurang & 0 & 1 & 1 & 2 & $\mathrm{C}=$ \\
& 0 & 50 & 50 & 100 & 0,400 \\
Cukup & 3 & 8 & 2 & 13 & \\
& 23,1 & 61,5 & 15,4 & 100 & \\
Baik & 2 & 9 & 0 & 11 & \\
& 18,2 & 81,8 & 0 & 100 & \\
\hline \multirow{2}{*}{ Total } & 5 & 18 & 3 & 26 & \\
& 19,2 & 69,2 & 11,5 & 100 & \\
\hline
\end{tabular}

\section{PEMBAHASAN}

\section{Faktor Predisposisi}

\section{Umur}

Hurlock membagi tingkatan-tingkatan umur menjadi tiga tingkatan yaitu tingkat awal masa muda (antara umur 18 sampai dengan 29 tahun), tingkat pertengahan (antara umur 30 sampai dengan 39 tahun), dan tingkat tua (lebih dari 40 tahun) (Hurlock, 1980). Hasil penelitian ini menunjukkan bahwa sebagian besar responden $(57,7 \%)$ termasuk dalam kategori umur tua ( $>40$ tahun). Sedangkan sebesar 7,7\% responden termasuk dalam tingkatan umur awal masa muda. Umur termuda responden adalah 28 tahun, dan umur responden tertua adalah 53 tahun.

Umur merupakan faktor penentu kinerja seseorang. Semakin tua umur seseorang, maka cenderung lebih terpuaskan dengan pekerjaannya. Ada sejumlah alasan yang melatarbelakangi kepuasan kerja mereka seperti pengharapan yang lebih rendah dan penyesuaian yang lebih baik terhadap situasi kerja karena mereka lebih berpengalaman. Pekerja yang lebih muda cenderung kurang terpuaskan karena berbagai pengharapan yang lebih tinggi, kurangnya penyesuaian diri dan penyebab-penyebab lainnya (Handoko, 1987).

Umur yang lebih tua seringkali dihubungkan dengan kematangan fisik dan mental seseorang. Pekerja dengan umur yang lebih tua diharapkan dapat menunjukkan perilaku yang lebih baik karena cenderung lebih berpengalaman dalam menghadapi situasi kerja tertentu dibandingkan dengan pekerja yang lebih muda.

\section{Masa Kerja}

Hasil penelitian menunjukkan masa kerja responden sebagian besar pada 13-23 tahun (57,7\%). Di urutan kedua terbesar yaitu 1-12 tahun (26,9\%).

Masa kerja biasanya dikaitkan dengan waktu mulai bekerja, pengalaman kerja juga ikut menentukan kinerja seseorang. Semakin lama masa kerja, maka kecakapan akan lebih baik karena sudah menyesuaikan diri dengan pekerjaannya. Seseorang akan mencapai kepuasan tertentu apabila telah menyesuaikan diri dengan lingkungannya. Semakin lama karyawan bekerja, mereka cenderung lebih terpuaskan dengan pekerjaan mereka. Para karyawan yang relatif baru cenderung kurang terpuaskan karena berbagai pengharapan yang lebih tinggi (Handoko, 1987). 


\section{Tingkat Pengetahuan tentang Perilaku Aman}

Berdasarkan hasil penelitian diketahui bahwa pengetahuan responden sebagian besar termasuk dalam kategori baik $(76,9 \%)$. Pengetahuan atau kognitif merupakan domain yang sangat penting untuk terbentuknya suatu tindakan seseorang (overt behavior). Dari pengalaman dan penelitian terbukti bahwa perilaku yang didasari oleh pengetahuan akan lebih langgeng daripada perilaku yang tidak didasari oleh pengetahuan (Notoatmodjo, 2003).

Seorang pekerja, dalam melakukan tindakan K3 perlu diberi pengetahuan terlebih dahulu agar mengerti dan sadar akan pentingnya tindakan tersebut, untuk mencegah terjadinya kecelakaan kerja. Pengetahuan mengenai perilaku aman dapat memengaruhi persepsi seorang pekerja, sehingga ia merasakan hal tersebut sebagai ancaman bagi dirinya. Hal tersebut dapat mendorong dirinya untuk melakukan tindakan K3 untuk mempertahankan dirinya dari kecelakaan kerja. Oleh karena itu, pekerja dengan tingkat pengetahuan yang lebih baik diharapkan memiliki kesadaran yang lebih baik hingga akhirnya dapat menunjukkan perilaku yang lebih baik pula.

\section{Sikap tentang Perilaku Aman}

Dari hasil penelitian diketahui bahwa sebagian besar responden termasuk dalam kategori sikap baik $(88,5 \%)$. Sikap merupakan reaksi atau respons seseorang yang masih tertutup terhadap suatu stimulus atau obyek. Dari berbagai batasan tentang sikap dapat disimpulkan bahwa manifestasi sikap itu tidak dapat langsung dilihat, tetapi hanya dapat ditafsirkan terlebih dahulu dari perilaku yang tertutup (Notoatmodjo, 2003).

Menurut Mar'at, sikap merupakan produk dan proses sosialisasi dimana seseorang bereaksi sesuai dengan rangsangan yang diterimanya. Sebelum orang itu mendapat informasi atau obyek itu, tidak mungkin terbentuk sikap. Suatu sikap dapat terbentuk pada individu karena adanya keyakinan akan akibat suatu perilaku. Sikap yang terbentuk ini dapat bersifat positif maupun negatif tergantung pada besarnya pengetahuan. Jadi semakin tinggi tingkat pengetahuan seseorang akan memengaruhi terbentuknya sikap dan selanjutnya diwujudkan dalam bentuk tindakan (Notoatmodjo, 2003).

Pada perilaku pencegahan kecelakaan kerja, sikap dipengaruhi oleh persepsi dan keyakinan akan ancaman kecelakaan dan keuntungan kerugian dari melakukan tindakan pencegahan tersebut.
Oleh karena itu pengetahuan akan bahaya yang ditimbulkan oleh kecelakaan kerja tersebut serta tindakan pencegahannya perlu diberikan terhadap pekerja.

\section{Frekuensi Pelatihan K3}

Pelatihan dapat digunakan sebagai strategi yang dikhususkan untuk perubahan perilaku, dengan cara mengarah pada diperolehnya keterampilan. Namun, selain untuk mengembangkan keterampilan, pelatihan juga memberikan perubahan pengetahuan seseorang mengenai suatu hal. Selain itu pelatihan juga dapat berfungsi untuk mempersiapkan orangorang guna melaksanakan pekerjaan mereka (Graeff, 1996).

Dengan pelatihan Keselamatan dan Kesehatan Kerja (K3) sebagai cues to action (pendorong untuk bertindak), diharapkan seorang pekerja mendapatkan pengetahuan dan informasi baru. Hal tersebut dapat memengaruhi seseorang dalam mendapatkan pengertian yang benar tentang kerentanan, kegawatan, dan kerugian dari tindakan pencegahan dan pengendalian yang dilakukan. Pemberian pelatihan juga dimaksudkan untuk meningkatkan kesadaran (awareness) mereka mengenai tindakan K3.

\section{Faktor Pemungkin}

\section{Frekuensi Penyelenggaraan Pelatihan K3}

Berdasarkan hasil penelitian dapat diketahui bahwa frekuensi penyelenggaraan pelatihan K3 di perusahaan termasuk dalam kategori sedang. Perusahaan mengadakan pelatihan K3 sebanyak 1 kali dalam 1 tahun, tetapi belum merata pada seluruh pekerja. Penyelenggaraan pelatihan K3 bertujuan untuk memberikan pengetahuan mengenai keselamatan dan kesehatan kerja dan keterampilan baru kepada pekerja, serta untuk memberi penyegaran dan me-remind mengenai aspek K3 dalam bekerja.

Para pekerja dilatih atau dikembangkan agar memperlihatkan perilaku (memberikan prestasi) sesuai dengan yang ditetapkan oleh perusahaan. Pelatihan menurut Siluka (1976) dalam Sialagan (2008), adalah proses pendidikan jangka pendek yang mempergunakan prosedur sistemnya dan terorganisir, sehingga pekerja non manajerial mempelajari pengetahuan dan keterampilan teknis untuk tujuan tertentu. Pelatihan digunakan untuk melatih pengetahuan dan keterampilan tertentu, keterampilan menggunakan peralatan, mesin, atau 
keterampilan manajerial, yang berlangsung dalam waktu yang relatif singkat dan dalam jangka waktu pendek baik untuk pekerja manajerial maupun untuk pekerja bukan manajer. Biasanya, perusahaan mempunyai pelatihan khusus untuk pekerja baru yang tidak melatih suatu keterampilan, tetapi diberikan pengetahuan tentang perusahaannya seperti visi dan misi perusahaan, prosedur kerja, kebijakan, dan peraturan tentang pekerjaannya. Program pelatihan ini bertujuan agar para pekerja dalam waktu singkat dapat mengenali dan menyesuaikan diri pada perusahaan dan budaya perusahaannya.

\section{Ketersediaan APD}

Berdasarkan hasil penelitian dapat diketahui bahwa ketersediaan APD terhadap jumlah pekerja di perusahaan termasuk dalam kategori baik. Ketersediaan APD mencukupi jumlah seluruh pekerja.

Untuk mewujudkan sikap menjadi suatu perbuatan nyata diperlukan faktor pendukung, atau suatu kondisi yang memungkinkan, antara lain adalah lingkungan fisik, tersedia atau tidak tersedianya fasilitas atau sarana yang merupakan sumber daya untuk menunjang perilaku (Handoko, 1987).

Sahab (1997) menjelaskan ketersediaan APD dapat mencegah perilaku tidak aman dalam bekerja. Fasilitas ketersediaan APD merupakan salah satu hal yang penting dalam mewujudkan penerapan keselamatan di tempat kerja. Penggunaan APD merupakan alternatif yang paling terakhir dalam hierarki pengendalian bahaya. Lebih baik mendahulukan tempat kerja yang aman, daripada melindungi pekerja dengan menggunakan APD.

\section{Pemasangan Peraturan}

Berdasarkan hasil penelitian dapat diketahui bahwa tidak ada pemasangan peraturan terkait larangan dan kewajiban pekerja di area kerja sehingga termasuk dalam kategori kurang. Peraturan merupakan dokumen tertulis yang mendokumentasikan standar, norma, dan kebijakan untuk perilaku yang diharapkan (Geller, 2001). Peraturan memiliki peran besar dalam menentukan perilaku aman yang mana dapat diterima dan tidak dapat diterima (Sialagan, 2008).

Peraturan keselamatan akan lebih efektif jika dibuat dalam bentuk tertulis kemudian dikomunikasikan dan didiskusikan dengan seluruh pekerja yang terlibat. Pekerja kemudian diminta untuk menandatangani pernyataan bahwa mereka telah membaca dan memahami peraturan tersebut dan juga telah mendapatkan penjelasan tentang konsekuensi apabila melanggarnya. Keterlibatan pekerja dalam perumusan peraturan akan membuat pekerja lebih memahami dan mau mengikuti peraturan tersebut (Roughton, 2002).

Goetsch (1996) memaparkan bahwa manajemen harus merumuskan peraturan yang sesuai, mengomunikasikan peraturan tersebut kepada pekerja, dan menegakkan peraturan tersebut di tempat kerja. Penegakan peraturan merupakan hal yang sering dilupakan.

\section{Pemasangan SOP}

Berdasarkan hasil penelitian dapat diketahui bahwa tidak ada pemasangan SOP di area kerja sehingga termasuk dalam kategori kurang. Pengusaha wajib menyediakan prosedur operasi tertulis yang berisi tentang proses operasi secara aman, termasuk langkah-langkah untuk tahapan operasi, batas operasi, pertimbangan keselamatan dan sistem keselamatan. Prosedur harus tersedia bagi karyawan yang memerlukan, dimutakhirkan secara berkala dan juga mencakup keadaan khusus.

Menurut Notoatmodjo (2003) salah satu strategi perubahan perilaku adalah dengan menggunakan kekuatan dan kekuasaan misalnya peraturan dan perundangan yang harus dipatuhi oleh pekerja. Cara ini menghasilkan perubahan perilaku yang cepat, akan tetapi perubahan tersebut belum tentu akan berlangsung lama karena perubahan perilaku yang terjadi tidak atau belum didasari oleh kesadaran diri. Sehingga dalam hal ini SOP merupakan hal yang harus dirumuskan, mengomunikasikan kepada pekerja, dan menegakkan SOP tersebut di tempat kerja.

Dalam upaya untuk meningkatkan keselamatan kerja, maka perilaku berisiko dapat dicegah. Tahap kepatuhan dimulai dari patuh terhadap anjuran/ instruksi. Seringkali kepatuhan dilakukan untuk menghindari hukuman atau untuk memperoleh imbalan jika memenuhi pedoman. Kepatuhan berikutnya adalah karena tertarik dengan melihat tokoh idola yang dikenal dengan tahap identifikasi. Perubahan perilaku tingkat kepatuhan yang baik adalah internalisasi, individu melakukan sesuatu karena memahami makna, mengetahui pentingnya tindakan dan keadaan ini. Hal ini cenderung akan berlangsung lama dan menetap dalam diri individu (Geller, 2001). 


\section{Faktor Penguat}

\section{Dukungan Teman Kerja}

Dalam teori perubahan perilaku oleh Lawrence Green, teman kerja termasuk dalam faktor pendorong (reinforcing) dimana perilaku maupun tindakan pekerja lain dianggap mampu memengaruhi sikap seseorang untuk bertindak. Teman kerja dapat pula termasuk dalam reference group (kelompok referensi) sehingga yang ia katakan atau perbuat cenderung untuk dicontoh (Notoatmodjo, 2003).

Menurut teori Health Belief Model (HBM), anjuran teman kerja dapat menjadi pendorong bagi seseorang untuk bertindak. Fungsi teman kerja dalam perubahan perilaku antara lain dalam memberikan informasi, saran, maupun ide mengenai Keselamatan dan Kesehatan Kerja (K3) di tempat kerja dengan tujuan bertambahnya pengetahuan serta menciptakan lingkungan kerja yang nyaman dan aman (Notoatmodjo, 2003).

\section{Dukungan Pimpinan/Pengawas}

Pengawas merupakan unsur kunci dalam program K3, karena pengawas adalah orang yang langsung berhubungan dengan tempat kerja dan pekerjanya. Pengawas paling tahu mengenai kondisi tempat kerja, dan memiliki otoritas untuk melakukan pengawasan dan pembinaan (Ramli, 2010).

Alfon (2006) menjelaskan kegunaan pengawasan adalah untuk menggantikan peran pertemuan safety meeting, selain itu dapat digunakan sebagai fungsi controlling pada pekerja dalam mengikuti seluruh hal yang telah dibahas dalam safety meeting.

Peran seorang pengawas sangat penting dan harus dapat memanfaatkan waktu dengan baik dalam berbicara, untuk memberitahukan ataupun memberikan teguran terhadap pekerja yang melakukan tindakan tidak aman dan memberikan pujian pada pekerja yang mengikuti prosedur kerja di tempat kerja. Kontak secara personal harus dilakukan sesering mungkin untuk memengaruhi sikap pekerja, pengetahuan, dan keterampilan (Bird dan Germain, 1990).

\section{Reward}

Berdasarkan hasil penelitian dapat diketahui bahwa tidak terdapat pelaksanaan pemberian reward di tempat kerja sehingga termasuk dalam kategori kurang. Menurut Mangkunegara (2005), imbalan yang diberikan kepada pekerja sangat berpengaruh terhadap motivasi. Oleh karena itu, pimpinan perlu membuat perencanaan pemberian imbalan dalam bentuk uang yang memadai agar pekerja terpacu motivasinya dan melakukan tindakan aman. Menurut penelitian Locke (1980) dalam Mangkunegara (2005), menyebutkan bahwa imbalan berupa uang jika pemberiannya dikaitkan dengan tujuan pelaksanaan tugas sangat berpengaruh terhadap peningkatan produktivitas kerja karyawan.

Menurut Geller (2001), penghargaan atau reward merupakan penguatan positif yang diterima pekerja ketika melakukan perilaku seperti yang diharapkan, sehingga pekerja akan cenderung melakukan perilaku yang diharapkan ketika mengetahui konsekuensi yang akan muncul. Pekerja lebih memiliki perasaan positif jika ia bekerja dengan tujuan untuk memperoleh sesuatu, daripada untuk menghindari kesalahan atau hukuman. Hal ini didukung oleh Notoatmodjo (2010) yang mengemukakan bahwa, perubahan perilaku cenderung mudah terjadi jika dapat memberikan keuntungan bagi individu yang bersangkutan.

\section{Punishment}

Menurut Fleming dan Lardner (2002) hukuman adalah suatu bentuk konsekuensi yang diterima oleh pekerja dengan harapan dapat memperkecil kemungkinan suatu perilaku untuk muncul kembali. Sementara dalam penelitian ini, hukuman diartikan sebagai bentuk konsekuensi yang timbul akibat pekerja berperilaku tidak aman ketika bekerja dalam bentuk pemberian sanksi administratif, pemotongan insentif, maupun sanksi lain yang diterapkan perusahaan.

Menurut Roughton (2002), hukuman tidak hanya berorientasi untuk menghukum pekerja yang melanggar peraturan, melainkan sebagai kontrol terhadap lingkungan kerja sehingga pekerja terlindungi dari insiden (kecelakaan kerja).

\section{Perilaku Aman}

Perilaku manusia merupakan hasil dari segala macam pengalaman serta interaksi manusia dengan lingkungannya yang terwujud dalam bentuk pengetahuan, sikap dan tindakan. Dengan kata lain perilaku merupakan respons/reaksi seorang individu terhadap stimulasi yang berasal dari luar maupun dari dalam dirinya (Notoatmodjo, 2003).

Menurut Katz dalam Notoatmodjo (2003) perilaku dilatarbelakangi oleh kebutuhan individu yang bersangkutan. Katz berasumsi bahwa 
perilaku berfungsi sebagai defense mechanism atau pertahanan diri dalam menghadapi lingkungannya. Artinya, dengan perilaku dan tindakannya, manusia dapat melindungi dirinya dari ancaman-ancaman yang datang dari luar.

Berdasarkan teori HBM, kemungkinan individu akan melakukan tindakan pencegahan tergantung secara langsung pada hasil dari dua keyakinan akan penilaian kesehatan (health belief) yaitu ancaman yang dirasakan dari sakit atau luka (perceived threat of injury or illness) dan pertimbangan tentang keuntungan dan kerugian (benefits and costs) (Notoatmodjo, 2003).

Apabila hal ini diterapkan pada perilaku K3 pada pekerja di lingkungan kerja yang berpotensi terhadap kecelakaan kerja, maka seorang pekerja akan berperilaku K3 atau melakukan praktek/ tindakan keamanan dalam bekerja untuk dapat melindungi dirinya dari ancaman-ancaman kemungkinan terjadinya kecelakaan kerja

\section{Hubungan Faktor Predisposisi dengan Perilaku Aman}

\section{Hubungan Umur dengan Perilaku Aman}

Berdasarkan hasil uji statistik dengan menggunakan kontingensi, diperoleh koefisien kontingensi sebesar 0,398 maka kuat hubungan antara umur terhadap perilaku aman responden adalah sedang.

Penelitian H.Meltzer dan D. Ludwig dalam Hurlock (1980) dikatakan bahwa rata-rata optimisme ingatan pada para pekerja paling tinggi pada kelompok usia 30-39 tahun. Sehingga pada rentang usia tersebut pekerja memiliki optimisme atau ingatan yang menyenangkan yang baik, dimana memengaruhi perilaku kerja mereka.

\section{Hubungan Masa Kerja dengan Perilaku Aman}

Berdasarkan hasil uji statistik dengan menggunakan kontingensi diperoleh koefisien kontingensi sebesar 0,328 maka kuat hubungan adalah sedang. Pengalaman untuk kewaspadaan terhadap kecelakaan bertambah baik sesuai dengan usia, masa kerja di perusahaan dan lamanya bekerja di tempat kerja yang bersangkutan. Pekerja baru biasanya belum mengetahui secara mendalam seluk beluk pekerjaan dan keselamatannya. Selain itu, mereka sering mementingkan dahulu selesainya sejumlah pekerjaan tertentu yang diberikan kepada mereka sehingga keselamatan tidak cukup mendapat perhatian. Oleh karena itu, masalah keselamatan harus dijelaskan kepada mereka sebelum melakukan pekerjaan dan bimbingan pada hari-hari permulaan bekerja adalah sangat penting (Suma'mur, 1996).

Dirgagunasa (1992) mengatakan bahwa, lama kerja seseorang jika dikaitkan dengan pengalaman kerja dapat memengaruhi kecelakaan kerja. Terutama pengalaman dalam hal menggunakan berbagai macam alat kerja. Semakin lama masa kerja seseorang maka pengalaman yang diperoleh akan lebih banyak dan memungkinkan pekerja dapat bekerja lebih aman.

\section{Hubungan Tingkat Pengetahuan tentang Perilaku Aman dengan Perilaku Aman}

Berdasarkan uji statistik kontingensi diketahui koefisien kontingensi sebesar 0,085 sehingga kuat hubungan antara pengetahuan dengan perilaku responden adalah lemah.

Pengetahuan merupakan hasil dari tahu, dan ini terjadi setelah seseorang melakukan pengindraan terhadap suatu objek tertentu. Pengindraan terjadi melalui panca indera manusia, yakni indera penglihatan, pendengaran, penciuman, rasa, dan raba. Sebagian besar manusia diperoleh melalui mata dan telinga. Kurang lebih $75 \%-87 \%$ dari pengetahuan manusia diperoleh/disalurkan melalui mata (Notoatmodjo, 2003).

Dalam bidang kesehatan, pengetahuan tertentu tentang kesehatan mungkin penting sebelum suatu tindakan kesehatan pribadi terjadi, tetapi tindakan kesehatan yang diharapkan mungkin tidak akan terjadi kecuali apabila seseorang mendapat isyarat yang kuat untuk memotivasinya bertindak atas dasar pengetahuan yang dimilikinya (Notoatmodjo, 2003).

\section{Hubungan Sikap tentang Perilaku Aman dengan Perilaku Aman}

Hasil uji statistik menggunakan uji kontingensi menunjukkan koefisien kontingensi 0,556 maka kuat hubungan antara sikap dan perilaku responden adalah kuat.

Menurut Fishein dan Ajzen, suatu sikap dapat terbentuk pada individu karena adanya keyakinan akan akibat suatu perilaku. Sikap yang terbentuk ini dapat bersifat positif maupun negatif tergantung pada besarnya pengetahuan. Jadi, semakin tinggi tingkat pengetahuan seseorang akan memengaruhi terbentuknya sikap dan selanjutnya diwujudkan dalam bentuk tindakan (Notoatmodjo, 2003). 
Suatu sikap belum otomatis terwujud dalam suatu tindakan (overt behavior). Untuk terwujudnya sikap menjadi suatu perbuatan nyata diperlukan faktor pendukung atau suatu kondisi yang memungkinkan, salah satunya yaitu dengan SOP dan peraturan yang berlaku.

\section{Hubungan Frekuensi Pelatihan K3 dengan Perilaku Aman}

Pelatihan dapat digunakan sebagai strategi yang dikhususkan untuk perubahan perilaku, dengan cara mengarah pada diperolehnya keterampilan. Namun, selain untuk mengembangkan keterampilan, pelatihan juga memberikan perubahan pengetahuan seseorang tentang suatu hal. Selain itu, pelatihan juga dapat berfungsi untuk mempersiapkan orangorang guna melaksanakan pekerjaan mereka (Graeff, dkk, 1996).

Dari uji statistik kontingensi diperoleh hasil koefisien kontingensi 0,255 maka kuat hubungan antara pelatihan K3 dengan perilaku aman adalah lemah. Menurut Lawrence Green pelatihan sebagai salah satu bentuk promosi kesehatan, jarang yang mempunyai efek yang bertahan lama. Karena itu suatu pelatihan agar mewujudkan perubahan perilaku perlu dilakukan secara rutin dan penyegaran kembali terhadap materi pelatihan (Notoatmodjo, 2003).

\section{Hubungan Faktor Penguat dengan Perilaku Aman}

\section{Hubungan Dukungan Teman Kerja dengan Perilaku Aman}

Berdasarkan uji statistik menggunakan uji kontingensi diperoleh koefisien kontingensi 0,400 sehingga kuat hubungan antara dukungan teman kerja dengan perilaku responden adalah sedang.

Teman kerja sebagai pendorong untuk bertindak (cues to action) diharapkan mampu memberikan informasi mengenai tindakan yang aman dalam bekerja serta mengenai bahaya yang ditimbulkan dari suatu tindakan. Menurut Poedjawijatna, pengetahuan tidak lain dari hasil tahu atau pengalaman sendiri atau dari pengalaman orang lain, artinya mengakui sesuatu terhadap atau dari sesuatu yang disebut putusan, sehingga pada dasarnya putusan dan pengetahuan itu sama (Notoatmodjo, 2003).

Hubungan atau interaksi pekerja merupakan hal yang penting dalam menciptakan iklim organisasi yang baik. Organisasi atau perusahaan dapat produktif jika orang yang ada dalam organisasi tersebut mampu berhubungan atau berinteraksi secara baik. Orang yang berinteraksi secara baik dapat menumbuhkan motivasi bekerja. Hal tersebut berdampak pada perilaku kerja yang aman dan terjadinya unsafe action pada pekerja yang memiliki interaksi baik dapat dihindari (Davis, 1989).

\section{SIMPULAN}

Hasil identifikasi menunjukkan bahwa mayoritas responden pada faktor predisposing meliputi umur pada rentang usia $>40$ tahun $(57,7 \%)$, masa kerja pada rentang 13-24 tahun $(57,7 \%)$, pengetahuan termasuk dalam kategori baik $(76,9 \%)$, sikap termasuk dalam kategori baik $(88,5 \%)$, dan frekuensi pelatihan $\mathrm{K} 3$ termasuk dalam kategori sedang $(42,3 \%)$. Pada faktor enabling meliputi frekuensi penyelenggaraan pelatihan K3 termasuk dalam kategori sedang, ketersediaan APD termasuk dalam kategori baik, pemasangan peraturan dan SOP termasuk dalam kategori kurang. Sedangkan pada faktor reinforcing meliputi dukungan teman kerja termasuk dalam kategori sedang (50\%), dukungan pimpinan/pengawas termasuk dalam kategori baik, pelaksanaan reward dan punishment termasuk dalam kategori kurang. Perilaku aman responden termasuk dalam kategori sedang $(69,2 \%)$.

Hasil analisis menunjukkan bahwa kuat hubungan antara faktor predisposing meliputi umur dengan perilaku aman termasuk dalam kategori sedang, masa kerja dengan perilaku aman termasuk dalam kategori sedang, tingkat pengetahuan dengan perilaku aman termasuk dalam kategori lemah, sikap dengan perilaku aman termasuk dalam kategori kuat, dan frekuensi pelatihan K3 dengan perilaku aman termasuk dalam kategori lemah. Sedangkan pada faktor reinforcing meliputi dukungan teman kerja dengan perilaku aman termasuk dalam kategori sedang.

\section{DAFTAR PUSTAKA}

Alfon, Patuan. 2006. Analisis Faktor-Faktor Tindakan Tidak Aman sebagai Penyebab Kecelakaan Kerja di Kegiatan Pemboran dan Produksi pada Beberapa Group KKKS Tahun 2002-2004. Tesis. Jakarta: Universitas Indonesia.

Bird, E.F., and Germain, G.L. 1990. Practical Loss Control Leadership (Edisi Revisi). Division of International Loss Control Institute. USA.

Davis, Keith. 1989. Human Behavior at Work, 8th ed. Singapore: McGraw-hill Inc. 
Dirgagunasa, Srigali. 1992. Pengantar Psikologi. Jakarta: Mutiara.

Fleming and Lardne. 2002. Strategies to Promote Safe Behavior as Part of a Health and Safety Management System. Health and Safety Executive. Norwich.www.hse.gov.uk/research/crr_pdf/2002/ crr02430.pdf (sitasi 25 Maret 2014).

Geller, E. Scoot. 2001. The Psychology Of Safety Handbook. USA: Lewis Publisher.

Geotsch, et. al. 1996. Safety and Health Management. Amsterdam Hall: Mac Gill Inc.

Graeff, J.A., J.P Elder, dan E. Mills. 1996. Komunikasi untuk Kesehatan dan Perubahan Perilaku. Yogyakarta: Gajah Mada University Press.

Handoko, H. 1987. Manajemen Personalia dan Sumber Daya Manusia. Edisi Kedua. Yogyakarta: BPFE.

Hurlock, E. 1980. Psikologi Perkembangan Suatu Penelitian Sepanjang Rentang Kehidupan. Jakarta: Erlangga.

Mangkunegara, Prabu A. 2005. Evaluasi Kinerja $S D M$. Bandung: PT Refika Aditama.

Notoatmodjo, S. 2003. Pendidikan dan Perilaku Kesehatan. Jakarta: Rineka Cipta.
Notoatmodjo, S. 2010. Promosi Kesehatan Teori dan Aplikasi. Jakarta: Rineka Cipta.

Ramli, Soehatman. 2010. Sistem Manajemen Keselamatan dan Kesehatan Kerja OHSAS 18001. Jakarta: PT Dian Rakyat.

Roughton, James E. 2002. Developing an Effective Safety Culture: a Leadership Approach. USA: Butterworth Heinemann.

Suma'mur. 1996. Higiene Perusahaan dan Kesehatan Kerja. Jakarta: PT Toko Gunung Agung.

Suma'mur. 2009. Higiene Perusahaan dan Kesehatan Kerja. Jakarta: PT Toko Gunung Agung.

Sahab, Syukri. 1997. Teknik Manajemen Keselamatan dan Kesehatan Kerja. Jakarta: PT Bina Sumber Daya Manusia.

Sialagan, Robin T. 2008. Analisis Faktor-Faktor yang Berkontribusi pada Perilaku Aman di PT EGS Indonesia Tahun 2008. Tesis. Jakarta: Universitas Indonesia.

Syaaf, Mashruri F. 2008. Analisis Perilaku Berisiko (At-Risk Behavior) pada Pekerja Unit Usaha Las Sektor Informal di Kota X. Skripsi. Jakarta: Universitas Indonesia. 